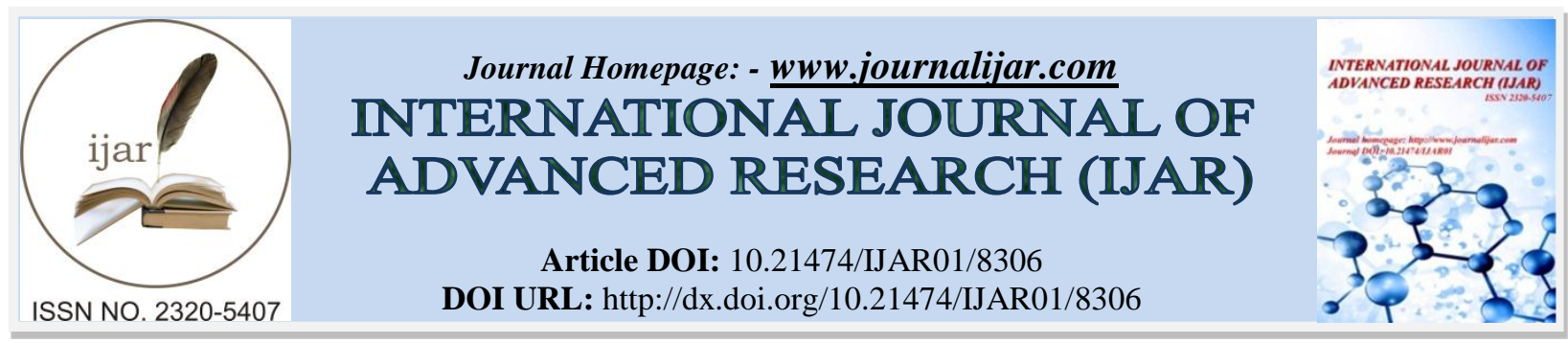

RESEARCH ARTICLE

\title{
ECONOMICS EDUCATION AND THE THEORY OF CONSUMER CHOICE, EXCERPTS FROM ECONOMICS TEXTBOOK MATERIALS.
}

James E Curtis.

$\mathrm{Jr}$, igri, po box 3126, washington de 20010.

\section{Manuscript Info}

Manuscript History

Received: 04 November 2018

Final Accepted: 06 December 2018

Published: January 2019

\begin{abstract}
Curtis Jr (2017) describes the objective of the university course, to convey intermediate and advanced concepts of consumer choice theory to students using explanatory, graphical and mathematical methods of analysis. The only prerequisite for this course is successful completion of Calculus, Principles of Microeconomics घ, or equivalent. After completing the requirements in this course, students should have a sufficient set of skills to thoroughly analyze interesting economic questions and to effectively participate in $(i)$ advanced undergraduate economics courses, (ii) core graduate economic theory courses, and (iii) graduate courses in the school of business, including MBA programs. The emphasis of this paper is that economics is the study of the efficient choices made by individuals, including consumers, workers, owners of firms and social planners $\square$ Policy writers, students and wealthy philanthropists reading this paper might conclude that corporate board members, and higher education endowment strategists and budget executives, should focus on and enhance the effectiveness of the individual, conditional on the capacity and constraints, whether they are innate, financial or political.
\end{abstract}

Copy Right, IJAR, 2018,. All rights reserved.

\section{Introduction:-}

Curtis Jr (2017) presents the teaching materials separately, attached to this document, presented in printed Microsoft Powerpoint slides created by James Edward Curtis Jr (2001) for projector transparency presentation by an instructor, and student study.

Reviewers include John C Ham, Ph.D. from Princeton University, Full/Tenured Professor \& Provost, Advisor; Tenured Professor and Provost; Richard H Steckel, Ph.D. from The University of Chicago, Retired Full/Tenured Professor, Retired Member of the University Faculty Senate, Co-Advisor;

2002 Curriculum Vita Of James E Curtis, Jr:-

Birth Information of James E Curtis, Jr:-

February 14, 1973anan Born $\square$ Washington, District of Columbia, WDC

\section{Corresponding Author:-James E Curtis.}

Address:-Jr, igri, po box 3126, washington dc 20010. 


\section{Education Information of James E Curtis, Jr:-}

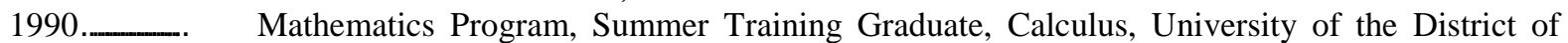
Columbia, WDC

1991-19940nandan. Bachelor of Arts Program, Department of Economics, Rutgers University, Camden, NJ

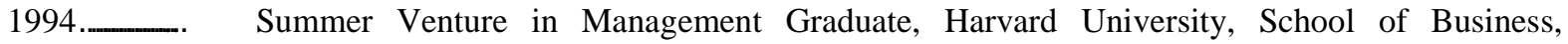

Cambridge, MA

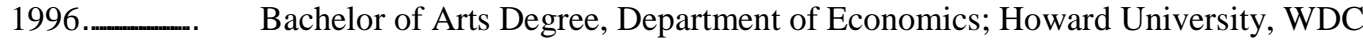

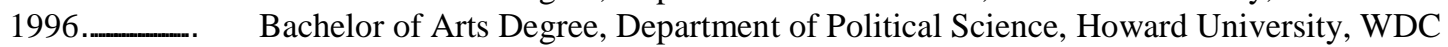

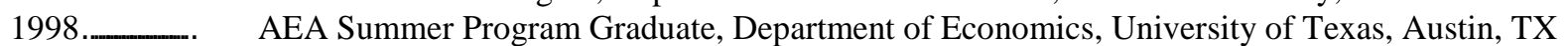

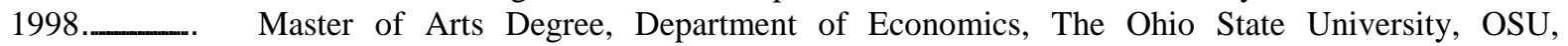

Columbus, $\mathrm{OH}$

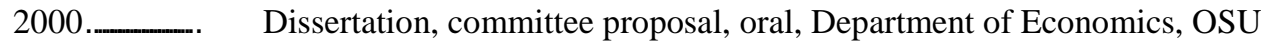

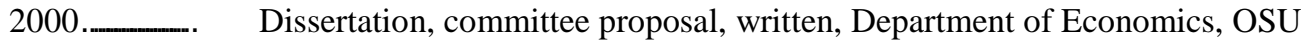

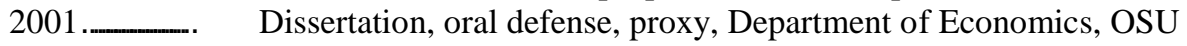

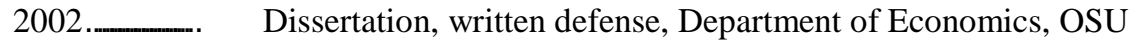

\section{Employment Information of James E Curtis, Jr:-}

1991 andandand Laws \& Economics Intern, USA, General Services Administration, WDC

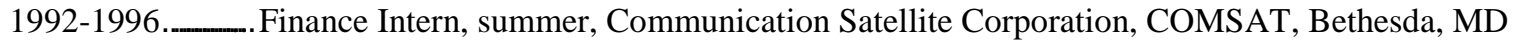

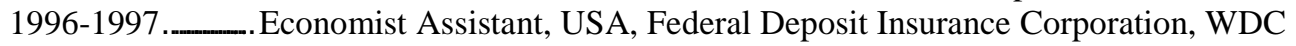

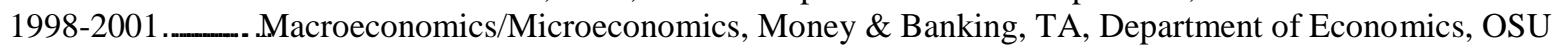

1999 Econandand

Columbus, $\mathrm{OH}$

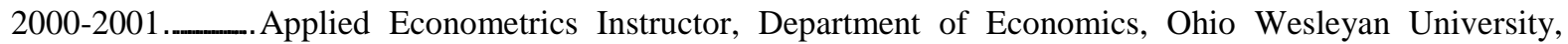
Delaware, $\mathrm{OH}$

2000-20010anandal.. Tutor, Department of Economics, OSU

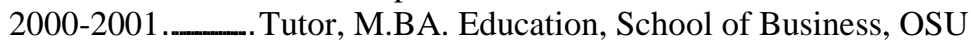

2000חם

2000-2002

Grant Recipient \& Research Supervisor, Department of Economics OSU

Grant Recipient \& Research Supervisor, Dissertation Grant, USA, National Science Foundation

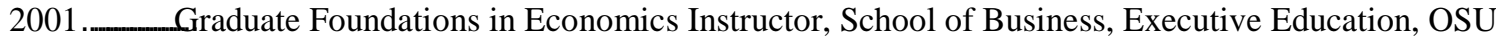
Intermediate Microeconomics Instructor, Department of Economics, OSU

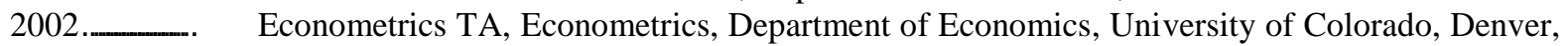
$\mathrm{CO}$

AEA Summer Program

Fundamentals of Graduate Econometrics, Graduate Teaching Assistant,

Employment Fields of Study and Research Fields of Competencies, Exams, Completed by James E Curtis, Jr:-

1. Economic History, 1999, Ph.D. pass of field exam, faculty, Department of Economics, The Ohio State University

2. Economic Theory, Macroeconomics, 1998 M.A./Ph.D. pass of qualifier exam, faculty, Department of Economics, The Ohio State University

3. Economic Theory, Microeconomics, 1998 M.A. pass of qualifier exam, faculty, Department of Economics, The Ohio State University

4. Economic Theory, Microeconomics, 1999 Ph.D. pass of qualifier exam, faculty, Department of Economics, The Ohio State University

5. Macroeconomics/Monetary Economics, 1999 Ph.D. pass of field exam, faculty, Department of Economics, The Ohio State University

Employment Fields of Study and Research Fields of Competencies, External, Approvals of James E Curtis, Jr:-

1. Applied Econometrics, 2001, approved by Steven Cosslett, Ph.D., Econometrics faculty, Department of Economics 
2. Applied Labor Economics, 2001, approved by Hajime Miyazaki, Ph.D., John C Ham, Ph.D., Labor Economics faculty, Department of Economics

3. Economics Education, 1998-2000 economics undergraduate education, approved by Belton Fleisher, Ph.D., Department of Economics

4. Economics Education, 2001 M.BA. education, approved by Ken Brevport, Ph.D. \& admin, Executive Education, School of Business, OSU

5. Economics Education, 2002 econometrics graduate education, approved by Charles Becker, Ph.D., Department of Economics

\section{References:-}

1. Curtis Jr, James Edward, $₫ A$ Theory of Wealth Accumulation Considering Modern Net Savings Gradualism The Impact of Unresolved Long Run Differences in Wealth Accumulation on the Annualized Net Savings in the USA $\llbracket$ Working Paper Number 3018488, (Available at SSRN: http://ssrn.com/ abstract=3018488), February 26, 2017.

2. Curtis Jr, James Edward, [Designing JECJEF University, Working Paper, July 31, 2017.

3. Curtis Jr, James Edward, Economics, A Student Textbook and Professor Manual for University Instruction of Microeconomics courses, 3rd Edition!, Working Paper, July 31, 2017.

4. Curtis Jr, James Edward, $\square$ Freedom Laws and Economics of Ethnicity $\square$ Working Paper Number 1701423 (Available at SSRN: http://ssrn.com/ abstract=1701423), January 23, 2012.

5. Curtis Jr, James Edward, [Long-Run Differences in Wealth: A Microdata Analysis of US White-Black Differences in Wealth Directly after Mass Emancipation of Southern Slaves』, Working Paper Number 1701373 (Available at SSRN: http://ssrn.com/abstract=1701373), December 1, 2002.

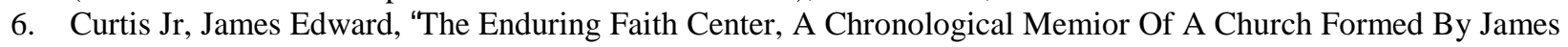
Edward Curtis Jr $\square$ Working Paper, December 31, 2013.

7. Curtis Jr, James Edward, ¿Wealth and Faith, What Is Your Real Reason? Is It Jesus? SSRN Working Paper Number 1793848 (Available at SSRN: http://ssrn.com/abstract=1793848), March 11, 2011.

8. Curtis Jr, James Edward, đWealth Discrimination Theory』, Working Paper Number 1751670 (Available at SSRN: http://ssrn.com/abstract=1751670), January 31, 2011.

9. Frank, Robert H. Microeconomics and Behavior, Boston: McGraw-Hill, 2000;

10. Mankiw, N. Gregory, Principles of Microeconomics, Fort Worth: Dryden, 1998;

11. Pindyck, Robert S. and Daniel Rubinfield, Microeconomics, Macmillan: Simon \& Schuster: New Jersey, 1995;

12. Stockman, Alan C. Introduction to Microeconomics, Fort Worth: Dryden, 1999;

13. Varian, Hal R. Intermediate Microeconomics: A Modern Approach, Norton: New York, 1999.

14. Varian, Hal R. Microeconomic Analysis, Norton: New York, 1992. 